\author{
NADIYA HNASEVYCH, \\ Ternopil National Economic University (Ternopil, Ukraine) \\ e-mail: nadiyahnasevych@gmail.com, ORCID 0000-0001-6844-1847
}

OLENA MORSHCHAKOVA,

Ternopil National Economic University (Ternopil, Ukraine)

e-mail:lenat19@ukr.net, ORCID0000-0002-1584-3479

\title{
PERSONAL DEVELOPMENT OF PERSON IN MODELS OF CULTURAL CREATION: ETHICAL-PHILOSOPHICAL REFLEXIA
}

The article deals with the issues of the essence of processes of personal development of a person as an implementation of its inner-spiritual potential. The subject of the research is formulated in the unity of the levels of conscious self-and world-attitude of the individual, which actualizes the problem of identity. The article focuses on the ethical components of the development of the internal-spiritual structure of the individual, it is stated that the value-semantic positions of the individual directly affect the development of consciousness and the identical formation of the person; the highest achievement of man in the processes of self-realization in the world of culture and public life, is a moral self-identification as a manifestation of conscious responsibility and responsibility of the individual in the plane of social expression. The source catalogue of the research distinguishes the works of philosophical, cultural and others spheres, in which the problem of personal development of person, the value-semantic parameters of its socio-cultural life is considered in the aspects of understanding the nature of the man searching for a meaning, the ability to cultural creation. Identification of unexplored parts of the general problem. The article focuses on the ethical dimensions of human existence in the modern world, emphasizing that a person is capable of cultivating the social environment due to the possibilities of inner-spiritual perception of reality and change of one's being. The human ethos unfolds in the direction of implementing processes of cultural cultivation, which has a decisive influence both on the processes of improving the inner world of the individual, and on the "cultural space" of the environment. According to the ethical and cultural approach, the problem of personal development of man is presented from the standpoint of philosophical and methodological analysis, research is concentrated on the creative meaning of such semantic concepts as "personality", "identity", "morality", "senses", etc. The author analyzes the ethical and semantic basis of personal self-determination of an individual, which originates as an individualized potential of the way out of the outer world and designing the "image of oneself" in the conditions of this world. The specificity of human personality development is based on the recognition of the principled dialogicity of human existence, expressed by the combination of the ideal orientation of the moral world of the human "self" and the problem of objective requirements of social reality as the practice of organizing interpersonal relations. The research presents a generalization according to which, under the influence of culture, a person undergoes internal transformations, which is a necessary condition for the creation of the identity, which is not derived directly from social influences, but is the result of reflection, comprehension, value relation, and efforts of self-consciousness - due to these cultural-making opportunities of a person the functioning of the world of everyday life is possible, modern personalized practices of life are being constructed and embodied in the collective forms of human coexistence.

Key words: personality; person; identification; moral identity; values; meanings.

\section{Introduction}

The personal development of a human is based on the recognition of the principled dialogicality of the human existence, expressed by the combination of the ideal orientation of the moral world of the human self, based on the idea of the meaning and purpose of life, life destination, happiness, etc., and the problem of objective requirements of social reality as practice of everyday life. In the conditions of the social environment - flowing, contradictory, situational, - the development of the substantially-individualized principle of man as a potential of its outward appearance, into a world which a person is capable of transforming according to his moral value judgments and to create optimal conditions for his own self-realization in this world.

The modern world of social relations is constructed on the semantic, technological, informational, personal and other levels, which actualizes the phenomenon of cultural growth in the form of personified samples and models of human behavior. The personal development of human is conditioned by culture: the more actively a person can 
contribute to the culture of society, the more effectively it will be able to return a culture accumulated by personal development and experience society. The neglect of cultural requests and the prospects of individual development for the personality, and with this personality, and for the whole range of social relations, there is a danger of the emergence of "post-human" reality, in which there will no longer be a place for a person. To this danger, the works of F. Fukuyama point out: "Our post-human future. Consequences of the Biotechnological Revolution", S. Lesh "Critique of Information", D. Lekur "Technique and life: human and posthuman". Modern postmodern philosophers write about the threat of a totally manipulated man, deprived of the autonomy of thought, of feelings - such a "post human" personality as a protagonist of the transhumanist movement may become a new version of man. In these conditions, the need for the formation of the inner world in the direction of strengthening cultural, moral beliefs, development of intellectual, volitional and other qualities that will allow an individual to fully reveal natural potential, make the world "human-dimensional", harmonizing social rhythms and paces of personal growth.

Given the risks inherent in modern social realities, the extraordinary complexity of social existence, its contradictions, the ambiguity of its value systems, the complexity of existential dimensions and trajectories of personal development, it should be noted that our time requires positive trends in socio-cultural progress and at the same time requires from an individual to take the active social position, the "effect of the presence" of a person in the social events to which she is involved, in order to withstand the adverse circumstances of our existence.

The problem of personal development of human as a philosophical problem is represented by a wide range of interpretations, views on the essential, self-assessing characteristics of human. Human being in aspects of the issues of freedom and self-enrichment are considered in the works of M. Berdyaev, O. Losev, M. Bakhtin, the existential and spiritual foundations of man's existence are covered in the writings of S. Kierkegaard, M. Heidegger, J.-P. Sartre. Thus, in the work of J.P. Sartre, "Existentialism is humanism," an idea that emphasizes the creative, active nature of man, his essential powers, is presented: "Man is a project that is subjectively experienced, not moss, not mold, and not a cauliflower ... A man will become what his project of being is. Not the way she wishes ... If existence really precedes the essence, then the person is responsible for what she is" (Sartre, 1953: 8).

The problem of orientation of the individual in the development of the subjective, inner world, is presented in the philosophical reflections $M$. Mamardashvili, according to whom the person "lives by the constant efforts of consciousness" (Mamardashvyly, 1988: 15). The context of the statement appeals to author's attention to cultural cultivation as a "work of life", which makes culture is presented as an opportunity for "an even greater culture" (Mamardashvyly, 1988: 16). Famous is the statement of the philosopher: "man is a being born of a second birth" (Mamardashvyly, 1988: 28), that is, a person capable of self-birth through culture, the perception of its symbolic forms, spiritual and semantic landmarks. The high mission of man, according to M. Mamardashvili, consists in "preventing evil" on the basis of human ability to intellectual effort ("spiritualized thinking" in accordance with moral laws, with morality, morality preceded by reasonableness, intellectual involvement in the ways of human activity, in which the expedient life activity of the subject manifests itself. The existence of a moral norm in human life means confirmation of the uniqueness of individual being, the ability to withstand the phenomena of cultural tyranny, manipulative influences, norms of morality act as prerequisites for securing the internally integral world of personality from manifestations of "fragmentation of morality" (A. Maclntyre) or external discrete interventions.

From the second half of the twentieth century. in the philosophical discourse there was the problem of the "mosaic" subject, identification and self-identification on the individual and social levels (J. Derrida, M. Foucault, P. Ricker, etc.), which in ethical aspect correlates with norms and practices of morality (E. Mclntyre, C. Taylor). Essays on themes of morality are deepened in search of possibilities of its comprehension as "truly human" (the concept of communicative ethics by K. Apel). In the postmodern perspective, all sociality is the practice of constructing identities, and the social space is open to radical personality reflections (J. Baudrillard, Z. Bauman, J. F. Lyotar). Thus, Z. Bauman confirms the idea that in the era of postmodernity the formation of a person's personality begins to turn from a "duty" to a "task", the task of "selfdetermination" of a person is reduced to a plane of active adaptation to the "prevailing social types and patterns of behavior, imitation of patterns, raising the cultural level, attempts not to retreat from the norm" (Bauman, 2002: 181-182). According to Z. Bauman, the existential world of man in the philosophical reflections of modernity acquires a certain semantic content, "understanding", due to "interpretive reason". In the thoughts of J.-P. Lyotard on the peculiarities of the formation of identities in "mature" societies, it is noted that the individual "I" of a modern person is a "reflexive project", responsibility for which the person carries: "We are what we create from ourselves" (Lyotar, 1998: 112).

The construction of "self-image", the formation of the value-semantic sphere and the sphere of human consciousness in the complexes of "experience", "understanding", "goal", "expression of will", "life experience", "reflexion", etc. forms the world of "actually human", the content of which is conditioned by cultural experience, which determines holistically the character of semantic consciousness, as well as spatial coordinates for the intellectual, ethical, spiritual self-development of the individual.

\section{Method}

The problem of personal development of man is presented in the article from the standpoint of ethical and philosophical discourse. In the proposed study the questions of the formation and development of the inner-spiritual potential of the individual are clarified, attention is focused on the ethical dimensions of human existence in the modern world. Research attention is concentrated on the creative meaning of such semantic concepts as "personality", "identity", "morality", "meanings", etc.

\section{Results and Discussion}

Acquiring the characteristics of a cultural person is a long-term process. This process is appropriate to compare with the metaphor of the "path" as a continuous formation, perfection and creative self-development. Man "carries" himself in the process of working together and communicating with other people, through the achievement of goals, perspective thinking and reflexive experience. Famous words by J.-P. Sartre, are the following "man is the future of man" (Sartre, 1953: 7). 
Personality development of a person is a cultural activity of a person in relation to himself, when a person acts as a subject and object of cognition and creative activity. Any culture is the result of both internal human efforts and external influences. Culture is taught, culture is cultivated. Extraordinary importance for the development of human consciousness, its internal potential, personal qualities have educational, socializing influences, through which the individual acquires value beliefs, and which form the basis for his further self-determination and self-identification, and will allow him to become the subject of activity in the future. Among the desirable personal qualities that an individual acquires as a result of activating processes of inner-spiritual development, one should note the following: awareness of the autonomy of his own Self, the sense of dignity, the feeling of inner freedom and responsibility, the ability of critical thinking, the ability to model the desired life situations, the desire for meaningful actions, the choice of positions, the implementation of actions, the ability to evaluate and reflexive analysis, the focus on cooperation, social expression of will. The most important for the individual result of external cultural influences, the role of which is the tendency towards the formation of self-organizing, self-disciplinary levers of human behavior is the presence of such personal internal motivational structures, through which the process of independent orientation and affirmation in the space of social relationships becomes possible. The constituent part of the process of cultural influences is the phenomenon of individuality of the individual socio-cultural constructs, choosing which to impose, a person is on the path of moral self-identification, self-presentation in the field of socio-cultural existence, and the choice of certain constructs is explained by irrational factors and reaches the depths of mental structures of the human psyche. The implementation of the process of inner-spiritual development is identified with the phenomenon of self-identification of the individual, which always contains an appeal to the external world, characterized by the presence of intentions (purposes) of man, which is expressed in many aspects of life-formation, in particular: behavioral, culturecreating, including the predictive and transcendental aspects.

Recognizing external cultural and educational influences, thanks to the concentrated analytical work, reflexioned experience, a person, to a great degree, simulates the world of those circumstances and events, which a person will face in life. The role of cultural and educational influences is intentionally projected to the level of the future human culture, the quality of its life path. Successful personal development of a person is conditioned by the necessity of forming social and individual qualities of a person in their complementarity, the purpose of this is the development of self-consciousness as the highest level of consciousness, since such anti phenomena as spirituality and asociality, destroy the meaning of the individual, and thus deny it.

Of course, the social factor has always occupied an important place in the system of factors of personality formation, while actualizing at the same time the task of improving society. Recalling the work of G.S. Skovoroda, in which the central place belongs to a person, the concept of "akin labor", the emphasis is placed on the fact that every person who has made his choice, has found his job, becomes free, since he is engaged in his favorite deed. In the theory of "akin" labor, responsibility for the future lies precisely on man, since the aim of self-knowledge in the name of personal happiness and public welfare to the realization of his vocation is the most desirable result of self-development of a person, the realization of its essential forces. The harmony that a person with inner peace and nature achieves is a guarantee of harmonious interaction of individuals in a society, the basic principle of which is "equal inequality", when the ideal of social justice becomes achievable, because everyone has a favorite employment. Moreover, man of work is a source of morality and moral behavior, public consciousness is formed as a normative, respectively, recognition of the rights and freedoms of the working man. The more responsible a person relates to his life's labor choice, the more important is the significance of labor morality in society, and hence the quality of relations between people. According to G.S. Skovoroda, it is extremely important that every person realizes his own responsibility to the world, which is a guarantee of healthy social relations. And today there is a conviction that still dates back to the Renaissance times, that each person is the creator of herself, which, in its likeness, creates both the state and society and culture. As E. Fromm noted, it is extremely important for a person to relate himself to any system that "guides her life and gives meaning; otherwise the person is filled with doubts that can paralyze the ability of a person to act, and, therefore, to live" (Fromm, 1998: 28). This means that, as a person is strained into society, its improvement, and society, in turn, must direct its interests to the needs and hopes of a person to prevent the process of alienation of man from society, and social life has not turned into a mechanical self-destructive process.

The conditions for the implementation of the processes of personal development are the affirmation of a person as a social being, with the ability to design own innerspiritual world for other people, to understand other people in the acts of communication, while preserving the harmonious unity of own "self", the "autonomy" and "selfsufficiency". That is, it should be emphasized that a prosperous social space is the basic condition for the deployment of processes of personality development in the direction of its accession to the cultural formants of society. In a disadvantaged social environment, there is an increase in the need to preserve "personal boundaries" of the vital and mental space of man, of individual selfworth.

By analyzing human behavior and its motives, V. Pareto differentiates "innate psychological pre-dispositions" (Pareto, 1978) (such as the "combination instinct", "the need for relaization in a social context") as driving impulses of social interaction, also pointing to camouflaging their "derivation "(Systems of pseudo-argumentation, pseudomotivation of actions, the purpose of which is a positive axiological characteristic of what happened). Obvious is the acceptance of the fact that many people have the character of mental stereotyped thinking with elements of immersion into the world of their own imagination, which often has nothing to do with reality. Somewhere, under this condition, a type of "autistic" thinking, an artificial construct is produced, which results in a "shutdown" of a person from reality, since the images of its inner world are much more "realistic" than the facts, they are unreality.

In A. Kamyu the fixation of tragic disorders of man as with the world of the individual "self", and the social world determined by the situation of "absurd" as a convincing evidence of loss of the meaning. Social cirmumstances, 
decisively contribute to (or, conversely, hinder) the realization of the semantic potential of the individual. Socium, devoid of meaning, is not so much indifferent as it is hostile to man. The modern German philosopher P. Slotterdijk points to the fundamental inability to understand the logic of the course of social processes, the nature of radical changes that transform the foundations of human being's mental existence. The situation that determines the state of consciousness of a modern man, he outlines with the expression "cynical mind", which in the interpretation of the philosopher is "enlightened false consciousness" (Slotterdijk, 2009: 59), a reflection of the decline of social existence. This is stated in the famous book "Critique of Cynical Reason". Ancient Greek word for "cynicism" is a category in the title of the work. In the classical version, the school of cynics contained fruitful guidelines in accordance with the requirements of the environment and taught "to be courageous before the challenges of destiny." Absolute significance acquired such spiritual values as individual freedom and independence. "Cynical reason" in P. Slotterdijk is beyond the limits of moral autonomy of man, is a statement of a profound split between the essential manifestations of social existence and the moral and spiritual guidelines of human consciousness. Output the thinker sees in search of answers to the challenges of "enlightened false consciousness" in the experience of "successful life," pointing to the need to recognize "various worlds of values" (Slotterdijk, 2009: 527). At the same time, protecting himself from the total sense of money, perhaps with the help of "ironic cynicism," in particular, R. Rorty confirms this idea: "Ironic is a typical modern intellectual" (Rorty, 1996: 123). German philosopher of ethics O. Giofe argues that modern societies are prepared for the dynamic transformations of the whole course of the development of world history, the very nature of man is characterized by "infinite variability" of overcoming crisis states (Hofe, 2003: 7). In the work of the thinker there is a loyalty to the Kantian "Sapere audi" ("Dare to think for yourself").

The personal self-determination of man is born as an individualized potency of reaching the outlines of the outer world and designing "self-image" in this world. Recalling the philosophical ideas of existentialists that "the acquisition of the essence of man precedes existence", the meaning of inner-spiritual dynamics in the development of a personal beginning is defined as the transition from the level of human existence - the individualized atomicity to the level of being of the individual as a subject of culture. Individual development is based on ideological positions, values, orientations, manifestations of a personal beginning, expressed through the problem of choice and freedom, etc. In any life, interpersonal, and public circumstances, an individual finds his own values and moral convictions. In ethical terms, the presence of a morally directed consciousness is a sign of the presence in a person of a truly human. The drama of the existence of a modern individual is associated with a devaluation of moral values, which means the destruction of coordination, regulating mechanisms of world perception and world affiliation.

The ontological basis of personal trajectories of human development is contained in semantic sphere. Meaning a person needs to find, there is a paradoxical philosophical statement that "there is no meaning in life, but it must be created by man", in this opinion - the whole life-asserting mission of meaning, the whole humanistic meaning of the concept. The ideological characteristics of meaning serve a person as cognitive, heuristic, activity levers in the organization of ideological notions and ethical and moral convictions.

In the creation of the semantic basis of individual and social being, the person is based on universal values, coordinating cultural semantic contexts with the practice of interpersonal communication. Such created meanings that have gained new sound in the realities of modern social life are: tolerance as a value through which, in the individual and public consciousness, perseverance will be acquired in relation to the elimination from practice of social relations of the phenomena of conflict, confrontation, as a result of the establishment of the basic principles between human communication, in the basis of which there are mutual recognition, mutual understanding, solidarity and mutual assistance.

Tolerance is a value criterion in the relationship of the cross-cultural, polylogical character, where the ethical component of the discovery of respect for the "identity of the Other" is advocated by necessity.

The concept of human dignity, the conceptual perspective of which is concentrated in the ethical, legal and humanitarian contexts, joins new semantic actuality. "Dignity" of a person is a sign of its self-worth and selfesteem, worthy, noble behavior. As the notion of "high moral", in the semantic aspect, "dignity" is the answer to the "value challenges" of time.

Formation of the principles of individual existence, the personal development of man is outlined by the dimensions of freedom, beyond which the creation of semantic reality and ideological system is devoid of meaning, because without the value-consciousness of the components of freedom as an objective data, man is not able to act as a person. No other concept reflects "the very human dimension of being", as the concept of "freedom". Freedom "creates" a person with a reasonable, responsible, independent being. I. Kant argued that the concept of "freedom" is identical to the concept of "personality". Freedom is a prerequisite for the existence of a moral dimension of man, the need for freedom embodies the most distinct features of human consciousness. The most important thing is that freedom is morality in its "positive reality," that is, for a particular person, the active purpose of freedom is to overcome its own egoism on the principles of self-improvement, as well as self-restraint, self-control, self-regulation.

Individual and social morals in their normatively determined virtues of dignity, justice, responsibility, honesty, decency, duty, trust, etc. are the focus of modern "social capital". Moral values can support "mentally healthy" communication in society, promote social consensus, understanding. The attachment to these values predetermines models of the "world of life", the choice of which is based on the praxeological and (practically wise) human possibilities. It is fundamentally important to emphasize that in the value-semantic consciousness of a modern person the interests of subjective-pragmatic nature dominate, and the process of formation of the meaning is accompanied by the search, design and reconstruction of semantic images that are adequate to the epoch of modernity.

In the processes of personal development and the semantic quest, the assessment-reflexive attitude of the individual to the normatively represented types of human actions is extremely important; the relation is a special manifestation, according to which the comparison of the 
qualities of some objects with others, their comparison with the opposite positions (good - bad, fair - unfair, moral - immoral). The principle of the relation manifests itself both in the search plan of the development of valuenormative valuation judgments, as well as to find out the modality of evaluation (relativity, subjectivity of evaluations).

Anything can be subjected to relativization: ethical principles, ideals, values, responsibilities, etc. The complication of human existence predetermines the complexity of ideas about life strategies, value choices, and the pur- pose of man. This assessment and reflection are a concentrated expression of the "attitude" of the individual to the inner world (the "soul of the world") and to the outer world (objective world of being in all its diversity of manifestations), accumulating indicators of value-selective attitude of man (Fig. 1). The experience of human being, reflected in consciousness, is reinterpreted and reinterpreted, which makes the semantic, inner-spiritual world of man, personal development, open to new generalizations, perspectives and opportunities.

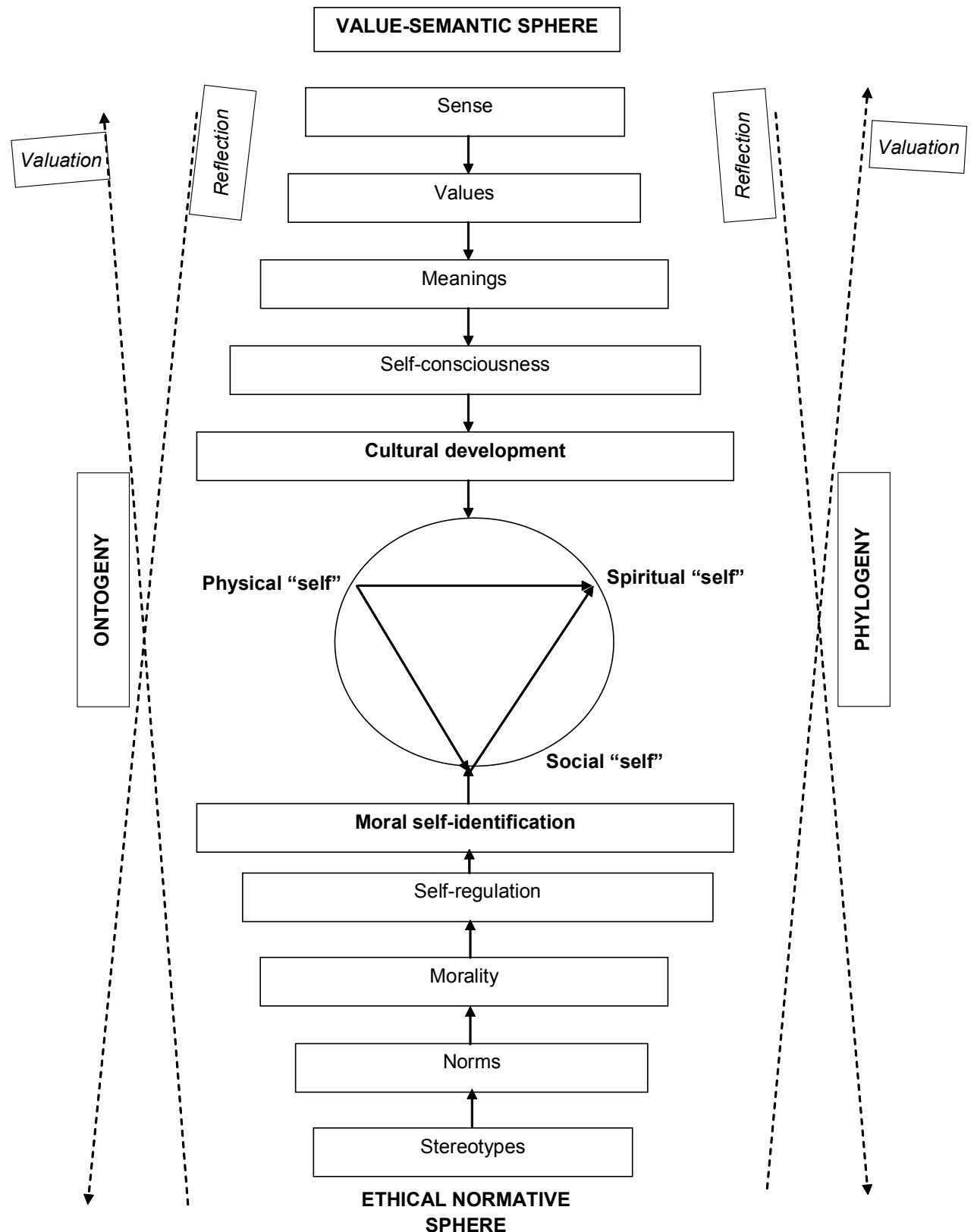

Fig. 1. The development of personality as a process

\section{Conclusions}

Personal development is a specifically human dimension of acquiring the essential characteristics of the innerspiritual world of the individual in the existential, essential manifestations of the individual. The directions of personal development of a man contain a fundamental solution in: the formation of semio-life strategies, the culture of world attitude, adherence to ethical norms, the resolution of internal psychological contradictions, the culture of attitude to situations of life, the culture of relations between people, etc. The dynamics and semantic filling of the concept of "personal development of man" points to its integral content characteristics, which unites the conceptual components into a single semantic field: "inner-spiritual development", "personality", "identity", "culture", "cultural influences ", "Culturology","morality". 
Under the influence of culture, a person undergoes internal transformations, which is a prerequisite for the creation of the identity, which is not derived directly from social influences, but is the result of reflection, comprehension, and efforts of self-consciousness. Man is capable of cultivating himself: the disclosure of his own human potential continues as a process of acquiring and improving personal characteristics. Under the influence of culture, a person undergoes internal transformations. The role of cultural and educational influences is intentionally projected to the level of the future human culture, the quality of its life path. Recognizing external cultural and educational influences, thanks to the concentrated analytical work, reflexioned experience, a person, to a great degree, simulates and the world of those circumstances and events, before which the facts will turn out to be in their lives. Successful personal development of a person is conditioned by the necessity of forming social and individual qualities of a person in their complementarity, with the purpose of which is the development of selfconsciousness as the highest level of consciousness, since such anti phenomena as spirituality, asociality, are destroying the meaning of the individual, and thus deny it.

The highest achievement of a person in the creation of identity, in the processes of self-realization in the world of culture and public life, is the moral self-identification as a manifestation of conscious duty and responsibility of the individual in the plane of social expression. Man is responsible for the development of his own inner world, his spiritual constants. Awareness of this responsibility to oneself, society, nature, transforms into the sphere of human cultural activity and into the problem of the implementation of moral choice. The universal content of personal development of man is the creation of the existential space of his life, an important characteristic of which is freedom, the boundaries of which have the ability to expand to the extent that a person is more oriented towards the knowledge of himself and the world.

\section{REFERENCES}

Baudrillard, Zh. (2004). Symuliakry i symuliatsiia [Simulacra and simulation]. (V. Khovkhun, Trans). Kyiv: Vyd-vo Solomii Pavlychko "Osnovy" (In Ukrainian).

Bauman, Z. (2002). Individualizirovannoe obshchestvo [Individualized society]. (V.L. Ynozemtseva, TransI.). Moscow. Lohos (In Russian).

Berdiaev, N. (1990). Samopoznanye. Opyt fylosofskoi avtobyohrafyy [Self-discovery. Experience of philosophical autobiography]. Moscow: Mezhdunarodnye otnoshenyia (In Russian).

Felicitas Munzel, G. (2019) Cultivating moral consciousness: The quintessential relation of practical reason and mind (Gemüt) as a bulwark against the propensity for radical evil, Educational Philosophy and Theory, 51 (13): 1351-1360. DOI: https:// doi.org/10.1080/00131857.2018.1532288

Frankl, V. (1990). Chelovek $v$ poiskakh smysla [Man's search for meaning]. Moscow: Prohress (In Russian).

Fromm, E. (1992). Dusha cheloveka [Soul of man]. Moscow: Respublika (In Russian).

Höffe, O. (2003). Rozum i pravo. Skladovi interkulturnoho pravovoho dyskursu [Reason and law. Components of intercultural legal discourse]. Transl. from Germ. Kyiv: Alterpress (In Ukrainian).

Kavalski, E. (2020). Inside/Outside and Around: Complexity and the Relational Ethics of Global Life, Global Society, DOI: https:/ /doi.org/10.1080/13600826.2020.1745158.

Krymskyi, S. B. (1992). Kontury dukhovnosti: novi konteksty indentyfykatsii [Outlines of Spirituality: New Contexts of Identification]. Voprosy fylosofii. 12: 38-64 (In Russian).

Krymskyi, S. B. (2003). Zapyty filosofskykh smysliv. [Requests for philosophical meanings]. Kyiv: Parapan (In Ukrainian).

Luman, N. (2007). Sotsyalnye sistemy. Ocherk obshchei teoryy [Social systems. Essay on the general theory]. St. Petersburg: Nauka (In Russian).

Lyotard, Zh.-F. (1998). Sostoianye postmoderna [The state of postmodern]. Moscow-SPb.: Aleteya (In Russian).

Mamardashvyly, M. (1988). Neobkhodimost sebia [Self need]. Moscow: Nauka (In Russian).

Mamardashvyly, M. (2014). Soznanye i tsivilizatsyia [Consciousness and civilization]. St.Petersburg: Lenyzdat (In Russian).

McIntosh, E. (2011). John Macmurray's Religious Philosophy: What it Means to be a Person. London/New York: Routledge Taylor and Francis Group, 278.

Moran, K. A. (2019). Misunderstanding duty: Vices of culture, 'aggravated' vice, and the role of casuistical questions in moral education. Educational Philosophy and Theory, 51(13): 13611371. DOI: https://doi.org/10.1080/00131857.2018.1516137

Morshchakova, O. S. (2013). Tsinnist u psykhokulturnomu butti liudyny yak osobystosti [Value in the psycho-cultural being of a man as a personality]. Ternopil: Psykholohiia i suspilstvo. 1, 80-89 (In Ukrainian).

Novhorodtsev, P. Y. (1991). Ob obshchestvennom ideale [About the public ideal]. Moscow: Pressa (In Russian).

Pareto, V. (1978). Complendio di sociologia generale. Torino. Lesco (In Italian).

Pazenok, V. S. (1990). Sotsialna kultura i sotsialna tvorchist [Social culture and social creativity]. Kyiv: Znannia (In Ukrainian).

Rorty, R. (1996). Sluchainost, ironiia i solidarnost [Accident, irony and solidarity]. Transl. from English: I.Heinstanoy, R.Hestanova. Moscow: Russian phenomenological society (In Russian).

Sartr, Zh.-P. (1953). Ekzystentsializm - eto humanizm [Existentialism is humanism]. Transl. from Fr. M.Hretskoi. Moscow: Izd-vo inostr. lit. (In Russian).

Shpet, H. H. (2007). Javlenie $i$ smysl [Phenomenon and meaning]. Moscow: Dyrekt-Medya (In Russian).

Shynkaruk, V. (1994). Vira, nadiia, liubov [Faith, Hope, Love]. Viche, 4: 145-150 (In Ukrainian).

Sloterdijk, P. (2009). Kritika cynicheskava razuma [Criticism of the Cynical Reason]. Transl. from germ. A.Pertsev. Ekaterinburg: U-Faktoriya, Moscow: AST Moscow (In Russian).

Steen, J. A. (2012). The Human Rights Philosophy as a Values Framework for the Human Behavior Course: Integration of Human Rights Concepts in the Person-in-Environment Perspective, Journal of Human Behavior in the Social Environment, 853-862.

Stepin, V. S. (1994). Filosofiia i obrazy budushcheho [Philosophy and images of the future]. Voprosy fylosofii, 6: 10-21 (In Russian).

Tabachkovskyi, V. H. (2006). Zhyttievyi svit liudyny i piznannia: personalistychna interpretatsiia [The vital world of man and cognition: a personalistic interpretation]. Filosofska dumka, 2: 34-48 (In Ukrainian).

Tsennosty [Values] (2003). Kultura i kulturolohyia. Slovar (A.Y.Kravchenko, red.). Moscow: Akademycheskyi proekt, Ekaterynburg. Delovaia knyha (In Russian). 


\author{
Надія Гнасевич, \\ Тернопільський наиіональний економічний університет (м. Тернопіль, Украӥна) \\ e-mail: nadiyahnasevych@gmail.com,ORCID 0000-0001-6844-1847
}

Олена Морщакова,

Тернопільський національний економічний університет (м. Тернопіль, Украӥна)

e-mail: lenat19@ukr.net, ORCID 0000-0002-1584-3479

\title{
ОСОБИСТІСНИЙ РОЗВИТОК ЛЮДИНИ В МОДУСАХ КУЛЬТУРОТВОРЕННЯ: ЕТИКО-ФІЛОСОФСЬКІ РЕФЛЕКСІї
}

\begin{abstract}
У статті досліджуються питання сутності процесів особистісного розвитку людини як реалізації їі внутрішнього духовного потенціалу. Тематика дослідження формулюється у єдності рівнів усвідомленого само- i світовідношення особистості, що актуалізує проблему ідентичності. У статті акцентується увага на етичних компонентах розвитку внутрішньої духовної структури особистості, зазначається, що ціннісно-смислові позиції особистості безпосередньо впливають на розвиток її свідомості та ідентичну сформованість; найвищим досягненням людини у процесах самоздійснення в світі культури й громадського життя, є моральнісна самоідентифікація як прояв усвідомленого обов'язку та відповідальності особистості у площині соціального самовираження. Джерельною базою дослідження виокремлено праці філософсько-культурологічного спрямування, в яких проблема особистісного розвитку людини, ціннісно-смислових параметрів її соціокультурного буття розглядається в аспектах розуміння природи смислопошуку людини, здатності до культуротворення. У статті акцентується увага на етичних вимірах існування людини у сучасному світі, підкреслюється, що людина здатна до культивування соціального середовища внаслідок можливостей духовного осмислення реальності й змінення власного буття. Етос людини розгортається в напрямку здійснення процесів культуротворчості, що має визначальний вплив як на процеси вдосконалення внутрішнього світу особистості, так і на "культурний космос" довкілля. Згідно етико-культурологічного підходу, проблематика особистісного розвитку людини представлена з позицій філософсько-методологічного аналізу, дослідницька увага концентрується на креативному значенні таких смислових концептів, як "особистість", "ідентичність", "моральність", "смисли" тощо. Проаналізовано етико-смислове підґрунтя особистісного самовизначення людини, яке зароджується як індивідуалізована потенція виходу до обріїв світу зовнішнього й проектування "образу себе" в умовах цього світу. Специфріка особистісного розвитку людини базується на визнанні принципової діалогічності людського існування, вираженої поєднанням ідеальної спрямованості моральнісного світу людського "я" та проблемою об'єктивних вимог соціальної реальності як практики організації міжособистісних відносин. Узагальнено, що під впливом культури людина зазнає внутрішніх трансформацій, щоє необхідною умовою творення ії ідентичності, яка не виводиться безпосередньо із соціальних впливів, але є результатом рефлексії, осмислення, ціннісного відношення, зусиль самосвідомості, - завдяки цим культуротворчим можливостям людини відбувається функціонування світу повсякдення, конструюються сучасні індивідуальні практики життя, втілюючись у колективних формах людського співіснування.
\end{abstract}

Ключові слова: особистість; ідентифрікація; моральнісна самоідентифрікація; цінності; смисли.

(c) Nadiya Hnasevych, Olena Morshchakova

Надійшла до редакції: 01.04.2020

Прийнята до друку: 08.05.2020 